Ethiopian Journal of Environmental Studies \& Management 9(3): 287 - 302, 2016.

ISSN:1998-0507

doi: http://dx.doi.org/10.4314/ejesm.v9i3.4

Submitted: November 23, 2015

Accepted: April 28, 2016

\title{
URBAN GREENING AND CITY SUSTAINABILITY IN IBADAN METROPOLIS, NIGERIA
}

\author{
*RAHEEM, W.M. ${ }^{1}$ AND ADEBOYEJO, A.T. ${ }^{2}$ \\ ${ }^{1}$ Department of Urban and Regional Planning, Faculty of Environmental Sciences, \\ University of Ilorin, P.M.B. 1515, Ilorin, Kwara State, Nigeria \\ ${ }^{2}$ Department of Urban and Regional Planning, Faculty of Environmental Sciences, \\ Ladoke Akintola University of Technology, P.M.B. 4000, Ogbomoso, Oyo State, Nigeria
}

\begin{abstract}
The pace of urbanisation, especially with cities in the developing world, has negatively influenced green areas and, as a consequence, threatened the several benefits provided by vegetation cover. Green areas provide shade, evaporative cooling, rainwater interception, and storage and infiltration functions, with impervious built surfaces. Consequently, the ecosystem services provided by urban green spaces are often overlooked and undervalued. The study uses primary data, which were obtained, through a random and systematic sampling of Three Hundred and Forty Four respondents. Variables used in the analysis include socio-economic characteristics of the respondents, the types of urban green space, benefits of urban green space to the respondents as well as the management strategies involved. Data collected were analysed using descriptive and inferential statistics. ANOVA result shows that there is significant variation in the types of urban greening with F-value of 4.920, 3.673, 4.822; and $p$-value of $0.001,0.006$ and 0.001 for road greening, residential greening and institutional greening respectively. Besides, the study reveals that most of the areas in the metropolis are more of concrete than open space with $41.8 \%$ covered up with $75 \%$ concrete, $18.4 \%$ with $50 \%$ coverage and $16.1 \%$ with $100 \%$ coverage while $14.3 \%$ was covered with $25 \%$ coverage and only $9.4 \%$ is less than $25 \%$ concrete coverage. The study therefore recommends the use of land development plan and the use of planning approval strategies among others, to ensure adequate room for urban green space in the metropolis.
\end{abstract}

Key Words: Urban Greening, City, Sustainability, Urban renewal and Metropolis

\section{Introduction}

Urban planning is not restricted only to the built environment such as housing and transportation network; rather, it includes the integration of green spaces into the physical urban landscape (Baycan-Levent, 2009). The urban green spaces literally encompass all public and private open spaces in urban areas mostly covered by vegetation which are directly or indirectly available for use (URGE, 2004). These include parks, gardens, allotments, wetlands, and urban trees among others.

Greening the urban environment has been variously recognized to offer

*Corresponding Author: Raheem, W.M.

Email: raheemwasiumayowa@gmail.com 
benefits of different kind to the urban milieu and the people (Cohen et al., 2008, 2002; Aldous, 2005; Crompton, 2001; Fam et al., 2008; Baycan- Levent and Nijkamp, 2009).This explains why planning concepts such as garden city, green belt, green fingers and greenways highlight the need to preserve the natural environment of urban areas by incorporating many green spaces into the design of cities (Collins, 2012).

According to Chiesura (2004), urban green areas are strategic to the quality of life in cities and evidence of the benefits and importance of these areas especially for environmental, ecological and esthetics. Other benefits include air and water purification, wind filtration, noise pollution mitigation and microclimate regulation, besides the social services such as socialization, recreation and crime prevention.

However, most cities of the world especially in the developing countries have suffered from acute depletion of green spaces principally due to rapid urbanisation, low resource base of institutions on green spaces, lack of priority to green spaces, corruption, political instability and uncooperative attitudes of the local people (Collins, 2012; Mckinney, 2002). For instance, 41 percent of lands reserved for green spaces in Europe have been lost to different land uses (EAA, 2002). Also, rapid urbanisation has caused many cities in West Africa such as Lagos, Kano, Kaduna, Sokoto (Nigeria), Dakar (Senegal), Freetown (Sierra Leone), Abidjan (Cote D'lvoire), Accra, Kumasi and Tema (Ghana) to lose substantial amount of urban green spaces to urban sprawl and infrastructural developments (Fuwape et al, 2011). Not exempted in this takeover of green space is Abuja (the capital city of Nigeria) even with all apparatus of government. (Fanan et al., 2011).

The consequences of outright absence and/or insufficiency of green spaces in urban area are enormous and challenging on the environment, and on the people. Environmentally, it has been established that lack of vegetative cover in urban areas makes many African cities "ecologically unfriendly" with configurations that compromise their resilience to climate change (FAO, 2012). Also, tampering with them could result in generating soil erosion, deforestation and their effects on the natural ecology of the environment and climate protection (Jibril, 2010). Flooding is a threat to many large cities, including Lagos, Ibadan and many other urban centres in Nigeria.

Also, as argued by Hall and TewdwrJones (2010), because water and vegetation are pleasant to most people; they are among the city elements with high imageability, which contribute to the formation of a mental map of a city, as well as its positive image. The use of images like mountains and trees to name districts and/or junctions in Ibadan metropolis is an age long tradition, however, while mountains and rivers are retained, perhaps because they are rigid structures that cannot be easily removed, most of the trees have long disappeared. For instance, many areas and districts in Ibadan metropolis named after trees are still in existence but with the trees long ago disappeared. E.g."Idi Obi", "Idi Ope" and "Idi Osan" translating to Kolanut tree area, Oil palm tree area and Citrus tree area respectively among others. Their disappearance is not unconnected with developments resulting from urbanisation 
without concern for their numerous benefits.

Ibadan with all its economic, social attributes as well as its status as administrative headquarters of both the old western region and the present Oyo state has suffered similar fate due to its uncontrolled and unplanned growth (Wahab, 2011). This rapid growth and haphazard plan leads to accelerated disappearance of natural habitat and urban green spaces. Like many cities in the developing world, Ibadan has grown in population and territorial expansion without any concern for the reduction of vegetative land cover, a development that has resulted in a number of environmental implications such as flooding, air pollution, loss of biodiversity and aesthetic pollution among others. Lack of priority for green spaces in the development agenda of the city has also hindered the growth of green spaces in the metropolis.

This study therefore attempts to assess the urban greening in Ibadan metropolis with a view to suggesting policy issues.

\section{Study Area}

Ibadan, one of the fastest growing cities in Nigeria is located in Oyo State in the south-west geo-political zone of Nigeria. It is the capital of Oyo State and lies on latitude $7^{\circ} 25^{\prime}$ North and longitude $3^{\circ} 5^{\prime}$ East and is located approximately $145 \mathrm{~km}$ north of Lagos and $530 \mathrm{~km}$ southwest of Abuja, the Federal Capital Territory. It also lies about $120 \mathrm{~km}$ east of the border with the Republic of Benin. It is situated close to the boundary between forest and grassland, which makes it a meeting point for people and products of both the forests and grassland areas. Ibadan is regarded as the largest indigenous city in tropical Africa.

The physical setting of the city consists of ridges of hills that run approximately in northwest - southeast direction. The largest of these ridges lies in the central part of the city and contains such peaks as Mapo, Mokola and Aremo. These hills range in elevation from 160 to 275 metres above sea level and thus afford the visitor a panoramic view of the city.

The average temperature of Ibadan is $27^{\circ} \mathrm{C}$, with a range of $4^{\circ} \mathrm{C}$; the mean annual rainfall is above $1,505 \mathrm{~mm}$ while the relative humidity is between $60 \%$ and $80 \%$. The vegetation, of Ibadan is rainforest. It has tall trees exist in different heights; they form canopies i.e. lower, middle and upper layers; it has numerous heterogeneous species of trees like Iroko, Obeche and Mahogany. 


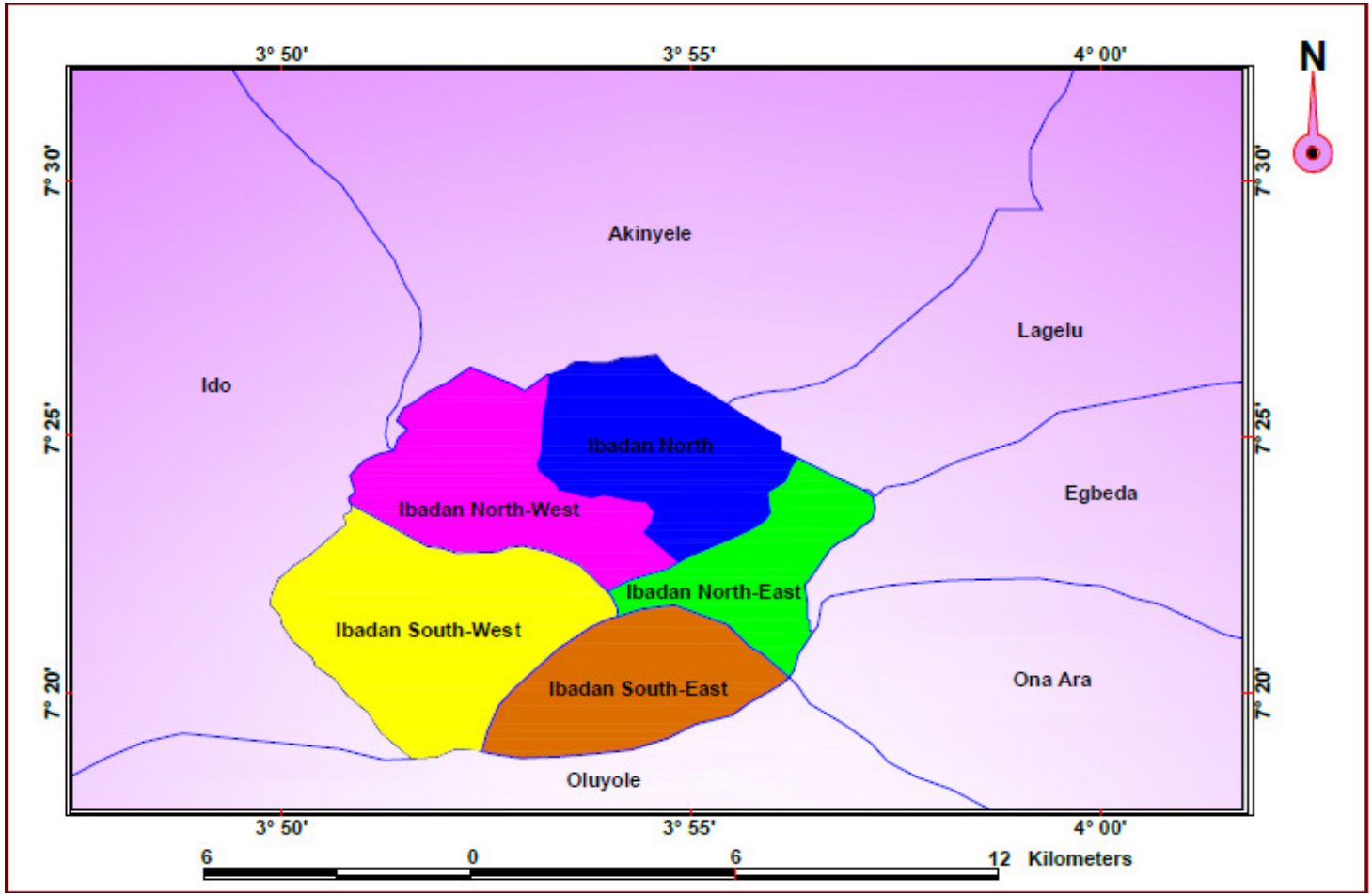

Figure 1: Ibadan Metropolis

\section{Methodology}

The study makes use of primary and secondary data, while the primary data were sourced from the respondents and reconnaissance survey, the secondary data were obtained by consultation with the ministry of environment for documents on government policy on urban greening programmes in the study area in particular and Oyo State in general.

Structured questionnaires were administered on 344 respondents from the five local government areas of Ibadan metropolis comprising ofIbadan North (Bodija), Ibadan North East (Iwo road), Ibadan South East (Mapo), Ibadan South West (Oluyole) and Ibadan North West
(Onireke) Local Governments. The systematic random sampling technique was used to select houses and random sampling was thereafter used to select the respondents.

Both descriptive and inferential types of analysis were carried out on the data. Descriptive analysis was used for analyzing data in the nominal and ordinal scale, where results were put in frequencies, percentages, and tables. Maps, charts and graphs were used appropriately to illustrate the result. Inferential Statistical tool of One-Way Analysis of Variance (ANOVA) was employed to examine the spatial variation in the types of urban green space across the study area. 


\section{Results and Discussion}

Table 1: Socio-economic characteristics of respondents in Ibadan Metropolis

\begin{tabular}{|c|c|c|}
\hline Socio-economic Variables & Frequency & Percentage $(\%)$ \\
\hline \multicolumn{3}{|l|}{ Gender } \\
\hline Male & 229 & 66.6 \\
\hline Female & 115 & 33.4 \\
\hline Total & 344 & 100.0 \\
\hline \multicolumn{3}{|l|}{ Age } \\
\hline $18-30$ Years & 60 & 17.4 \\
\hline $31-40$ Years & 71 & 20.6 \\
\hline $41-50$ Years & 96 & 27.9 \\
\hline $51-60$ Years & 88 & 25.6 \\
\hline 61 and Above & 29 & 8.4 \\
\hline Total & 344 & 100.0 \\
\hline \multicolumn{3}{|l|}{ Marital Status } \\
\hline Single & 59 & 17.2 \\
\hline Married & 267 & 77.8 \\
\hline Divorced & 11 & 3.2 \\
\hline Separated & 1 & 0.3 \\
\hline Widow & 5 & 1.5 \\
\hline Total & 344 & 100.0 \\
\hline \multicolumn{3}{|l|}{ Ethnicity } \\
\hline Yoruba & 267 & 77.6 \\
\hline Igbo & 58 & 16.9 \\
\hline Hausa & 11 & 3.1 \\
\hline Non Nigeria & 4 & 1.2 \\
\hline Others & 4 & 1.2 \\
\hline Total & 344 & 100.0 \\
\hline \multicolumn{3}{|l|}{ Educational qualification } \\
\hline No formal Education & 22 & 6.4 \\
\hline Quranic education & 6 & 1.7 \\
\hline Primary Education & 31 & 9.0 \\
\hline Secondary Education & 94 & 27.4 \\
\hline Tertiary Education & 189 & 55.0 \\
\hline No response & 2 & 0.5 \\
\hline Total & 344 & 100.0 \\
\hline \multicolumn{3}{|l|}{ Occupation } \\
\hline Not employed & 45 & 13.1 \\
\hline Farming & 5 & 1.5 \\
\hline Artisan & 43 & 12.5 \\
\hline Self-employed & 68 & 19.8 \\
\hline Trading and business & 93 & 27.0 \\
\hline Civil Service & 89 & 25.9 \\
\hline No response & 1 & 0.2 \\
\hline Total & 344 & 100.0 \\
\hline \multicolumn{3}{|l|}{ Income (Monthly) } \\
\hline Below US\$250 & 158 & 52.8 \\
\hline US\$255 - US\$500 & 98 & 32.8 \\
\hline US\$505 - US\$750 & 27 & 9.0 \\
\hline US\$755 - US\$1000 & 11 & 3.7 \\
\hline US\$1005 - US\$1250 & 2 & 0.7 \\
\hline US\$1255 and above & 3 & 1.0 \\
\hline Total & 299 & 100.0 \\
\hline
\end{tabular}


The study reveals majority male with $66.6 \%$ while the female has $33.4 \%$, this is supported by (NPC, 2006). The age structure reveals that majority of the respondents fall in the age structure between the ages 41 and 50 years with $27.9 \%$.

Respondents' distribution by ethnicity indicates majority of Yoruba with $77.6 \%$. Others are Igbo $16.9 \%$, Hausa with $3.2 \%$, other Nigerian ethnicity has $1.2 \%$ while non-Nigerian makes up $1.2 \%$. This distribution is quite understandable owning to the fact that Ibadan is one of the ancient Yoruba cities.

Furthermore, the study reveals that married people constitute the bulk of the respondents with $77.6 \%$, a development that could lead to higher population density and impact negatively on green space areas (Fuwape and Onyekwelu, 2011).

The study also indicates more than half of the respondents with tertiary education certificate $(55.3 \%)$. This is followed by secondary and primary education with $27.5 \%$ and $9.1 \%$, while $6.4 \%$ and $1.8 \%$ are recorded for no formal education and Quranic education respectively. It can be deduced from this therefore that the respondents are generally informed and this might have gone a long way to enhance the study.

In the distribution of respondents in the occupational category, most of the respondents are into trading $(27 \%)$, civil servants $(25.9 \%)$ followed by selfemployment (19.8\%), unemployed (13.1\%), artisan (12.5\%) and farming $(1.5 \%)$. The highest percentage recorded by trading might not be far from the increasing rate of unemployment in the country pushing many to find ways to eke out a living.

Income distribution according to the study shows that majority of the respondents $(52.8 \%)$ fall below US\$250 while another significant proportion $(32.8 \%)$ claims they earn between US\$255 and US\$500 (9.0\%) in the US\$505 - US\$750 category, while 3.7\%, $1.0 \%$ and $0.7 \%$ earn between US\$755 US\$1000, US\$1005 - US\$1250 and US\$1255 and above respectively. The study confirms the general observation that people in the developing world consider income issue very personal and something to be hidden from public knowledge. The reason for this is to a greater extent due to the fear of increased taxation and some other levies that many think may accompany such information.

Table 2: Types of Urban Greening in Ibadan Metropolis

\begin{tabular}{lll}
\hline Types of urban green space & Frequency & Percentage (\%) \\
\hline Road greening & 58 & 17 \\
Public squares and parks & 17 & 5 \\
Residential green space & 167 & 49 \\
Institutional green space & 73 & 21 \\
River greening & 29 & 8 \\
Total & 344 & 100 \\
\hline
\end{tabular}

As indicated in table 2, generally, the study finds that $(17 \%)$ of the metropolis has road greening, 5\% constitutes public squares and parks, $49 \%$ has residential green space, $21 \%$ institutional green space and $8 \%$ river greening. It can thus be deduced that residential green space dominates in the metropolis, followed by 
institutional green space; this may not be unconnected with the domination of residential land use in the metropolis, as $40-50 \%$ of urban land allocation is devoted to residential land use (Obateru, 2005). Institutional green space coming second might be as a result of large expanse of space devoted for open space by institutions such as educational and administrative institutions. Public squares and parks greening recording a low percentage is an indication that such type of green space in Ibadan metropolis is less developed.
As can be seen from the table 3 , the combined landscaping records the highest Ibadan metropolis with $60.1 \%$, while hard landscaping has $23 \%$ and soft landscaping records the lowest with $16.9 \%$. By implication, the preponderance of hard landscaping in the metropolis is perhaps largely responsible for the incessant occurrence of erosion and flood ravaging the city almost on yearly basis resulting in loss of lives and properties.

Table 3: Types of Landscape in the metropolis

\begin{tabular}{lll}
\hline Landscape types & Frequency & Percentage (\%) \\
\hline Hard landscaping & 79 & 23 \\
Soft landscaping & 58 & 16.9 \\
Combined landscaping & 207 & 60.1 \\
Total & 344 & 100.0 \\
\hline
\end{tabular}

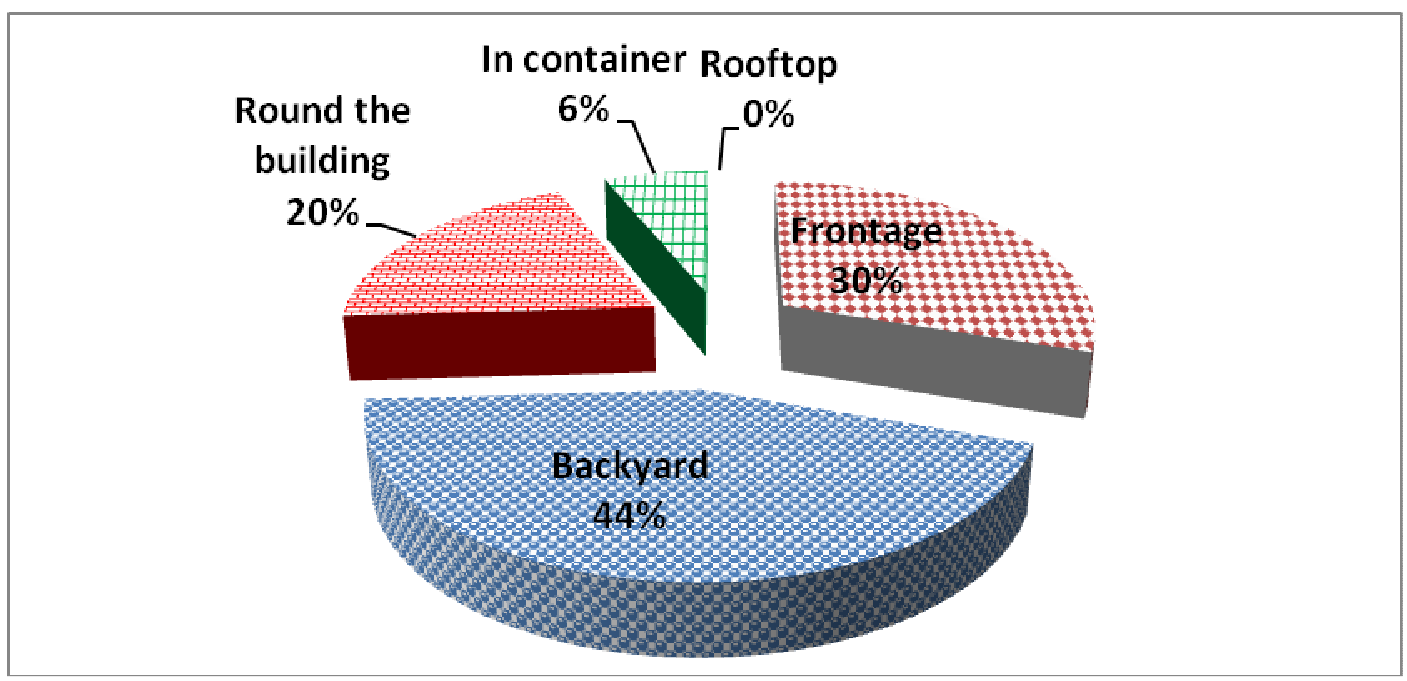

Figure 2: Distribution of Green Space

Figure 2 reveals the distribution of green space at different locations in Ibadan metropolis, it shows that green space at backyard records $44 \%$, in the frontage of building $30 \%$, while having green space round the building has $20 \%$ and in container $6 \%$. It is however noteworthy that rooftop green space is not available at all in the study area. While substantial numbers of building have backyard green space though at low coverage, the frontage green space is quite low, this might not be unconnected with other land uses into which frontal 
setbacks are put, such as commercial activities and placement of makeshift shops among others.

Of particular interest here is the $0 \%$ presence of greening on the roof. From this, it can generally be deduced that at diverse degree, green spaces are available at different locations in the respondents' residence except on the roof. The absence of roof top greening may be attributable to the cost, lack of technology, (Qazi, 2010) knowledge and resources to develop such designs in this part of the world and conservatism on the part of the people.

Table 4: Percentage coverage of concrete in the residence

\begin{tabular}{llllllll}
\hline \multirow{2}{*}{ Local government } & \multicolumn{9}{l}{ Percentage coverage of concrete } & \\
\cline { 3 - 6 } & & $\mathbf{2 5 \%}$ & $\mathbf{2 5 \%}$ & $\mathbf{5 0 \%}$ & $\mathbf{7 5 \%}$ & $\mathbf{1 0 0 \%}$ & Total \\
\hline Ibadan North & Number & 14 & 21 & 15 & 27 & 2 & 79 \\
& Row \% & 17.7 & 26.6 & 19 & 34.2 & 2.5 & 100 \\
Ibadan North East & Column \% & 43.8 & 42.9 & 23.8 & 18.9 & 3.6 & 23.1 \\
& Number & 4 & 6 & 5 & 50 & 20 & 85 \\
& Row \% & 4.7 & 7.1 & 5.9 & 58.8 & 23.5 & 100 \\
& Column \% & 12.5 & 12.2 & 7.9 & 35 & 36.4 & 24.9 \\
Ibadan North West & Number & 3 & 7 & 12 & 12 & 3 & 37 \\
& Row \% & 8.1 & 18.9 & 32.4 & 32.4 & 8.1 & 100 \\
Ibadan South east & Column \% & 9.4 & 14.3 & 19.0 & 8.4 & 5.5 & 10.8 \\
& Number & 8 & 8 & 17 & 21 & 14 & 68 \\
& Row \% & 11.8 & 11.8 & 25 & 30.9 & 20.6 & 100 \\
Ibadan south west & Column \% & 25 & 16.3 & 27 & 14.7 & 25.5 & 19.9 \\
& Number & 3 & 7 & 14 & 33 & 16 & 73 \\
& Row \% & 4.1 & 9.6 & 19.2 & 45.2 & 21.9 & 100 \\
Total & Column \% & 9.4 & 14.3 & 22.2 & 23.1 & 29.1 & 21.3 \\
& Number & 32 & 49 & 63 & 143 & 55 & 342 \\
& Row \% & 9.4 & 14.3 & 18.4 & 41.8 & 16.1 & 100 \\
& Column \% & 100 & 100 & 100 & 100 & 100 & 100 \\
\hline
\end{tabular}

$\mathrm{X}^{2}=62.476, \mathrm{df}=6, \mathrm{p}=0.000$

Table 4 is the presentation of percentage coverage of concrete of respondents' residences. It shows that $41.8 \%$ of residence with $75 \%$ concrete, $18.4 \%$ with $50 \%$ coverage and $16.1 \%$ with $100 \%$ coverage while $14.3 \%$ claimed their own residence is $25 \%$ coverage and only $9.4 \%$ of residence is less than $25 \%$ concrete. This can thus be interpreted to mean that majority of the residences in the study area $76.3 \%$ have half of their plot area covered with concrete surface. This can be adduced to be reason why the city experience excessive heat and flooding because most of the open spaces that could have served as openings for percolation have been covered up.

This might also account for excessive heat experienced in the city centre which on many occasions results into ailments such as meningitis, small pox and other heat related diseases (Adeboyejo et al., 2012). Also, concrete surfaces are known to generate Urban Heat Island (UHI), excessive run off leading to flood and also likely to result in high rate of energy consumption due to high energy demand for air conditioning and others (Solecki et al., 2008) 
It can be noted also that, most of the buildings go contrary to the planning standard that stipulates $40 \%$ development of plot area. This implies high impervious surfaces and goes to show the extent to which urban surfaces are concrete. The overall effects of this phenomenon can be numerous ranging from excessive heat, high runoff and flooding. It may also result in shortage of water as water table might be far away the immediate surface.

\section{Spatial Variation in the Types of Urban Green Spaces in Ibadan Metropolis}

Earlier analyses show differences in the types of urban green spaces across the local government areas; however, the study intends to see the statistical variation and therefore uses ANOVA tools to establish the result of variation. Some of the greening types available are road greening, public parks and squares, residential green space, institutional green space, river greening; and other greenings and the result is presented in the table 5

Table 5: Analysis of Variance (ANOVA) of variation in types of Green Spaces in Ibadan ANOVA

\begin{tabular}{|c|c|c|c|c|c|c|}
\hline & & $\begin{array}{l}\text { Sum of } \\
\text { Squares }\end{array}$ & df & Mean Square & $\mathrm{F}$ & Sig. \\
\hline \multirow{3}{*}{ Road greening } & Between Groups & 3.511 & 4 & .878 & \multirow[t]{3}{*}{4.920} & \multirow[t]{3}{*}{.001} \\
\hline & Within Groups & 60.486 & 339 & .178 & & \\
\hline & Total & 63.997 & 343 & & & \\
\hline \multirow{3}{*}{$\begin{array}{l}\text { Public parks and } \\
\text { squares }\end{array}$} & Between Groups & .181 & 4 & .045 & \multirow[t]{3}{*}{.666} & \multirow[t]{3}{*}{.616} \\
\hline & Within Groups & 23.002 & 339 & .068 & & \\
\hline & Total & 23.183 & 343 & & & \\
\hline \multirow{3}{*}{ Residential green space } & Between Groups & 2.893 & 4 & .723 & \multirow[t]{3}{*}{3.673} & \multirow[t]{3}{*}{.006} \\
\hline & Within Groups & 66.755 & 339 & .197 & & \\
\hline & Total & 69.648 & 343 & & & \\
\hline \multirow{3}{*}{ Institutional green space } & Between Groups & 3.988 & 4 & .997 & \multirow[t]{3}{*}{4.822} & \multirow[t]{3}{*}{.001} \\
\hline & Within Groups & 70.105 & 339 & .207 & & \\
\hline & Total & 74.093 & 343 & & & \\
\hline \multirow{3}{*}{ River greening } & Between Groups & .790 & 4 & .198 & \multirow[t]{3}{*}{1.818} & \multirow[t]{3}{*}{.125} \\
\hline & Within Groups & 36.835 & 339 & .109 & & \\
\hline & Total & 37.625 & 343 & & & \\
\hline \multirow{3}{*}{ Others } & Between Groups & .015 & 4 & .004 & \multirow[t]{3}{*}{.637} & \multirow[t]{3}{*}{.636} \\
\hline & Within Groups & 1.974 & 339 & .006 & & \\
\hline & Total & 1.988 & 343 & & & \\
\hline
\end{tabular}

Table 5 shows results of ANOVA establishing spatial variations in the types of green spaces availability in the metropolis of Ibadan. According to the table, types of greening spaces vary significantly across the metropolis, while others reported no statistical significance in the study area. In actual fact, out of six variables of urban greening, three were found to have significantly varied, while the remaining three are observed to have reported otherwise. For instance, road greening, residential green spaces, and institutional green spaces observed to have F- values of 4.920, 3.673, 4.822; and P-values of $0.001,0.006,0.001$ respectively. This implies that there is significant variation in the existence of 
road greening, residential and institutional green spaces at $\mathrm{P}<0.05$ confidence level. It can however, be inferred that availability of road greening, residential and institutional green spaces do not remain the same across the Local Government Areas of Ibadan metropolis under study.

In a sharp contrast, it is also observed from table 5 that public park and squares, river greening; and other greenings do not significantly vary with $\mathrm{F}$-values of
$0.666,1.818,0.637$ and $\mathrm{P}<$ values of $0.616,0.125,0.636$ respectively. It can however, be established that there is no statistical variation in the existence of public park and squares, river greening; and other greenings, at $\mathrm{P}<0.05$ confidence level. The implication of this finding is that the situation of public park and squares, river greening; and other greenings is actually the same things across the metropolis of Ibadan.

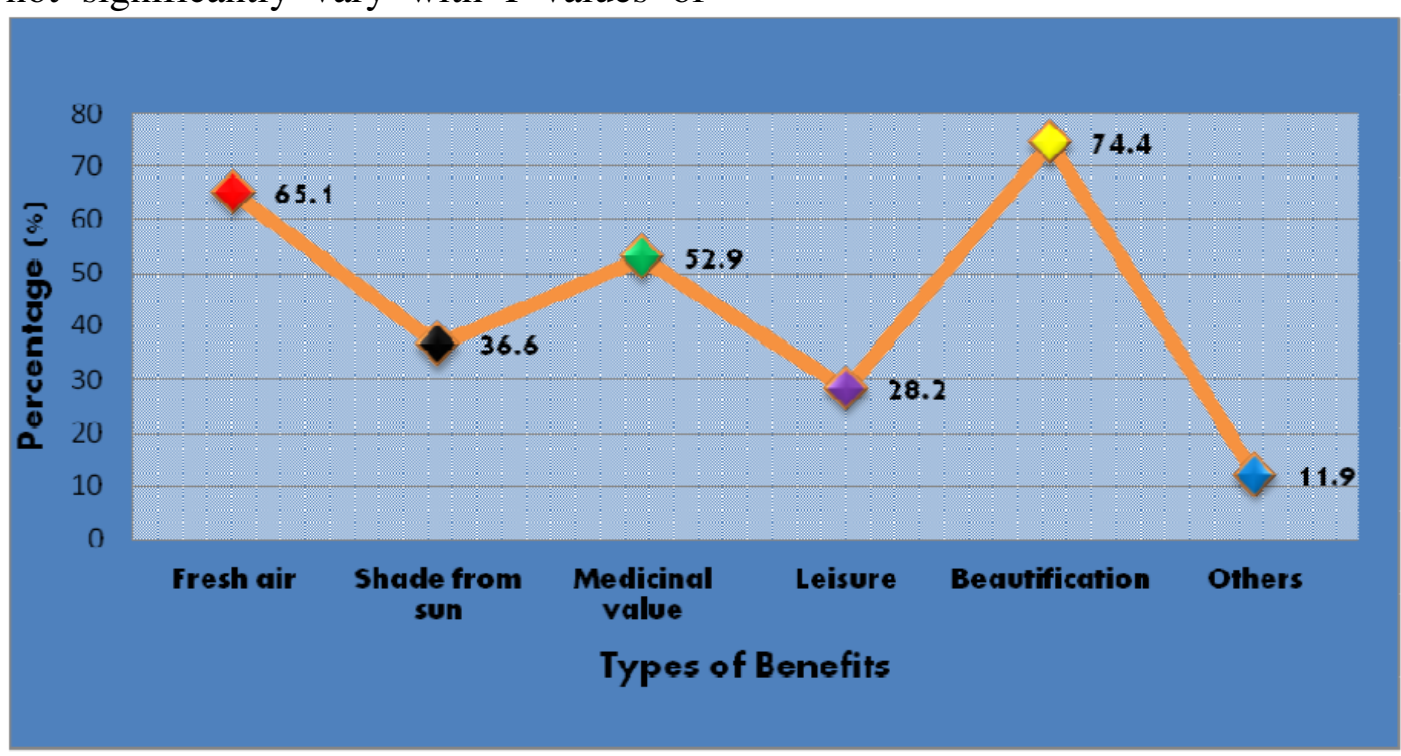

Figure 3: Benefits of Urban Green Spaces

Figure 3 reveals the various benefits offered by urban green space as given by the respondents. $74.4 \%$ of them claimed the benefit to be beautification, fresh air has $65.1 \%$ and $52.9 \%$ goes for medicinal value. Also, the respondents who agreed to urban green space benefits in terms of shade from the sun are $36.6 \%$ while $28.2 \%$ and $11.9 \%$ are for leisure and others respectively.

It can thus be inferred from the figure that majority of the respondents agreed urban green spaces provide aesthetic for urban environment, this might not be unconnected with the age long attachment to flowers as means of decoration and beautification.

Another striking result here is the medicinal value with $52.9 \%$. For the fact that Ibadan is an indigenous city, it may not be out of place that most of the respondents have awareness of using one or two roots, bark and/or leaves of trees for therapeutic purposes. Besides, culturally, many people in this part of the world are familiar with the value of leaves and root of shrubs and tree for alternative medicinal purpose. The low percentage recorded by leisure as indicated by the figure might be as a result of the traditional nature of the people of metropolis. 
Table 6: Other benefits of green space

\begin{tabular}{|c|c|c|c|c|c|c|c|c|c|c|c|c|c|c|c|}
\hline \multirow{2}{*}{$\begin{array}{l}\text { Local } \\
\text { Government } \\
\text { Area }\end{array}$} & \multicolumn{3}{|c|}{ Reduction of Runoff } & \multicolumn{3}{|c|}{ Purification of Air } & \multicolumn{3}{|c|}{ Protection of Biodiversity } & \multicolumn{3}{|c|}{ Provision of Employment } & \multicolumn{3}{|c|}{ City Image } \\
\hline & Yes & No & $\begin{array}{l}\text { Total } \\
\text { No }\end{array}$ & Yes & No & $\begin{array}{l}\text { Total } \\
\text { No }\end{array}$ & Yes & No & $\begin{array}{l}\text { Total } \\
\text { No }\end{array}$ & Yes & No & $\begin{array}{l}\text { Total } \\
\text { No }\end{array}$ & Yes & No & $\begin{array}{l}\text { Total } \\
\text { No }\end{array}$ \\
\hline Ibadan N (\%) & 55.7 & 44.3 & 79 & 41.8 & 58.2 & 79 & 46.8 & 53.2 & 79 & 16.5 & 83.5 & 79 & 20.3 & 79.7 & 79 \\
\hline Ibadan NE (\%) & 41.2 & 58.8 & 85 & 41.2 & 58.8 & 85 & 57.6 & 42.4 & 85 & 97.6 & 2.4 & 85 & 32.9 & 67.1 & 85 \\
\hline Ibadan NW (\%) & 41.0 & 59.0 & 39 & 43.6 & 56.4 & 39 & 41 & 59 & 39 & 17.9 & 82.1 & 39 & 15.4 & 84.6 & 39 \\
\hline Ibadan SE (\%) & 45.6 & 54.4 & 68 & 44.1 & 55.9 & 68 & 45.6 & 54.4 & 68 & 30.9 & 69.1 & 68 & 35.3 & 64.7 & 68 \\
\hline Ibadan SW (\%) & 32.9 & 67.1 & 73 & 32.9 & 67.1 & 73 & 34.2 & 65.8 & 73 & 46.6 & 53.4 & 73 & 26.0 & 74.0 & 73 \\
\hline Total (\%) & 43.6 & 56.4 & 344 & 40.4 & 59.6 & 344 & 45.9 & 54.1 & 344 & 45.9 & 54.1 & 344 & 27.0 & 73.0 & 344 \\
\hline
\end{tabular}

Reduction of runoff: $\mathrm{X}^{2}=8.532, \mathrm{df}=4, \mathrm{p}=0.074$

Purification of air: $X^{2}=2.354, \mathrm{df}=4, p=0.671$

Protection of biodiversity: $\mathrm{X}^{2}=9.118, \mathrm{df}=4, \mathrm{p}=0.058$

Provision of employment: $\mathrm{X}^{2}=137.688, \mathrm{df}=4, \mathrm{p}=0.000$

City image: $X^{2}=8.418, \mathrm{df}=4, \mathrm{p}=0.077$

Table 7: Impediments to urban green spaces in Ibadan metropolis

\begin{tabular}{|c|c|c|c|c|c|c|c|c|c|c|c|c|}
\hline \multirow{2}{*}{$\begin{array}{l}\text { Local } \\
\text { Government Area }\end{array}$} & \multicolumn{3}{|c|}{ Lack of space } & \multicolumn{3}{|c|}{ Poor attitude of the people } & \multicolumn{3}{|c|}{ Competition with other land uses } & \multicolumn{3}{|c|}{ Poor management techniques } \\
\hline & Yes & No & Total No & Yes & No & Total No & Yes & No & Total No & Yes & No & Total No \\
\hline Ibadan $\mathrm{N} \%$ & 42.9 & 57.1 & 77 & 41.6 & 58.4 & 77 & 28.6 & 71.4 & 77 & 36.4 & 63.6 & 77 \\
\hline Ibadan NE \% & 98.8 & 1.2 & 84 & 52.4 & 47.6 & 84 & 94.0 & 6.0 & 84 & 27.4 & 72.6 & 84 \\
\hline Ibadan NW $\%$ & 35.9 & 64.1 & 39 & 35.9 & 64.1 & 39 & 38.5 & 61.5 & 39 & 53.8 & 46.2 & 39 \\
\hline Ibadan SE \% & 45.5 & 54.5 & 66 & 37.9 & 62.1 & 66 & 40.9 & 59.1 & 66 & 42.4 & 57.6 & 66 \\
\hline Ibadan SW \% & 55.6 & 44.4 & 72 & 26.4 & 73.6 & 72 & 55.6 & 44.4 & 72 & 61.1 & 38.9 & 72 \\
\hline Total $\%$ & 59.2 & 40.8 & 338 & 39.6 & 60.4 & 338 & 54.1 & 45.9 & 338 & 42.6 & 57.4 & 338 \\
\hline
\end{tabular}

Lack of space: $\mathrm{X}^{2}=77.387, \mathrm{df}=4, \mathrm{p}=0.000$

Poor attitude of the people: $\mathrm{X}^{2}=11.415, \mathrm{df}=4, \mathrm{p}=0.022$

Competition with other land uses: $X^{2}=82.729, \mathrm{df}=4, \mathrm{p}=0.000$

Poor management techniques: $\mathrm{X}^{2}=21.289, \mathrm{df}=4, \mathrm{p}=0.000$ 
From table 6, it can be observed that $55.7 \%$ of the respondents claimed that urban green space help in reduction of runoff while the least in terms of reduction of runoff is Ibadan Southwest with $32.9 \%$, for purification of air, Ibadan Northwest dominates with $43.6 \%$ while the least is Southwest with $32.9 \%$. responses to protection of biodiversity as the benefit derived from urban green space shows that Ibadan Southwest is leading with $65.8 \%$, while others are in the ranges of $59 \%$ for Ibadan Northwest, $54.4 \%$ Southeast and $53.2 \%$ Ibadan North.

It can be deduced that the respondents are aware of one benefit or the other of green spaces, of particular reference as far as the study area is concerned is the use of green spaces as city image, it is a common practice in Ibadan as done elsewhere to use trees as landmarks either for identification and/or description of places E.g "Idi Arere", "Idi Oro", "Idi Osan" and "Idi Ope" among others literally translating to- on the side of "Arere" tree, Mango tree, Citrus tree and Oil palm tree respectively. Although, these planning ideas predated modern planning, they are still in vogue in the study area up till date.

Shown in table 7 is the distribution of diverse problems facing urban green space in the study areas and as responded to by the respondents, $59.2 \%$ of the respondents report lack of space for urban greening activities, while poor attitude towards urban green space, competition with other land use and poor management have $39.6 \%, 54.1 \%$ and $42.6 \%$ respectively.

It can therefore be inferred that lack of space is a dominant problem against urban green space in Ibadan metropolis. This development may not be far from the truth considering the land value in the urban centres especially where maximum use of land is put into consideration for maximum returns. This largely explains the relevance of the theory of "The Four Zone City Model" of Smit et al. (1996) used in this study where green spaces in the core area are usually restricted to steep slopes, railway lines, in containers and land not suitable for development among others primarily due to lack of space for such activities.

Table 8: Factors responsible for disappearance of urban green space in Ibadan metropolis

\begin{tabular}{lll}
\hline Factors for disappearance & Frequency & Percentage $(\%)$ \\
\hline Dumping of refuse & 18 & 11.2 \\
Erection of structure & 97 & 60.2 \\
Lack of maintenance & 43 & 26.7 \\
Insecurity & 3 & 1.9 \\
Total & 161 & 100 \\
\hline
\end{tabular}

Using table 8 , it is revealed that of all the factors contributing to the decreasing of urban green spaces in the study area, erection of structure has the highest proportion with $60.2 \%$, this is followed by lack of maintenance $26.7 \%$, while dumping of refuse and insecurity have $11.2 \%$ and $1.9 \%$ respectively.
It can thus be inferred that erection of structure in most of the hitherto vacant spaces have now been developed, this is expected as the value of land in urban centres appreciate daily and therefore prompts owners to either develop them or sell them out to buyers whose target is solely to maximize returns. This 
development, as previously identified therefore restricts green spaces to slopes, rivers and wedges where development cannot be supported. This finding is not different from that of previous studies of this nature where urbanization has been among other factors, singled out to have been responsible for the destruction of urban green spaces (Collins, 2014; Opkala, 2009)

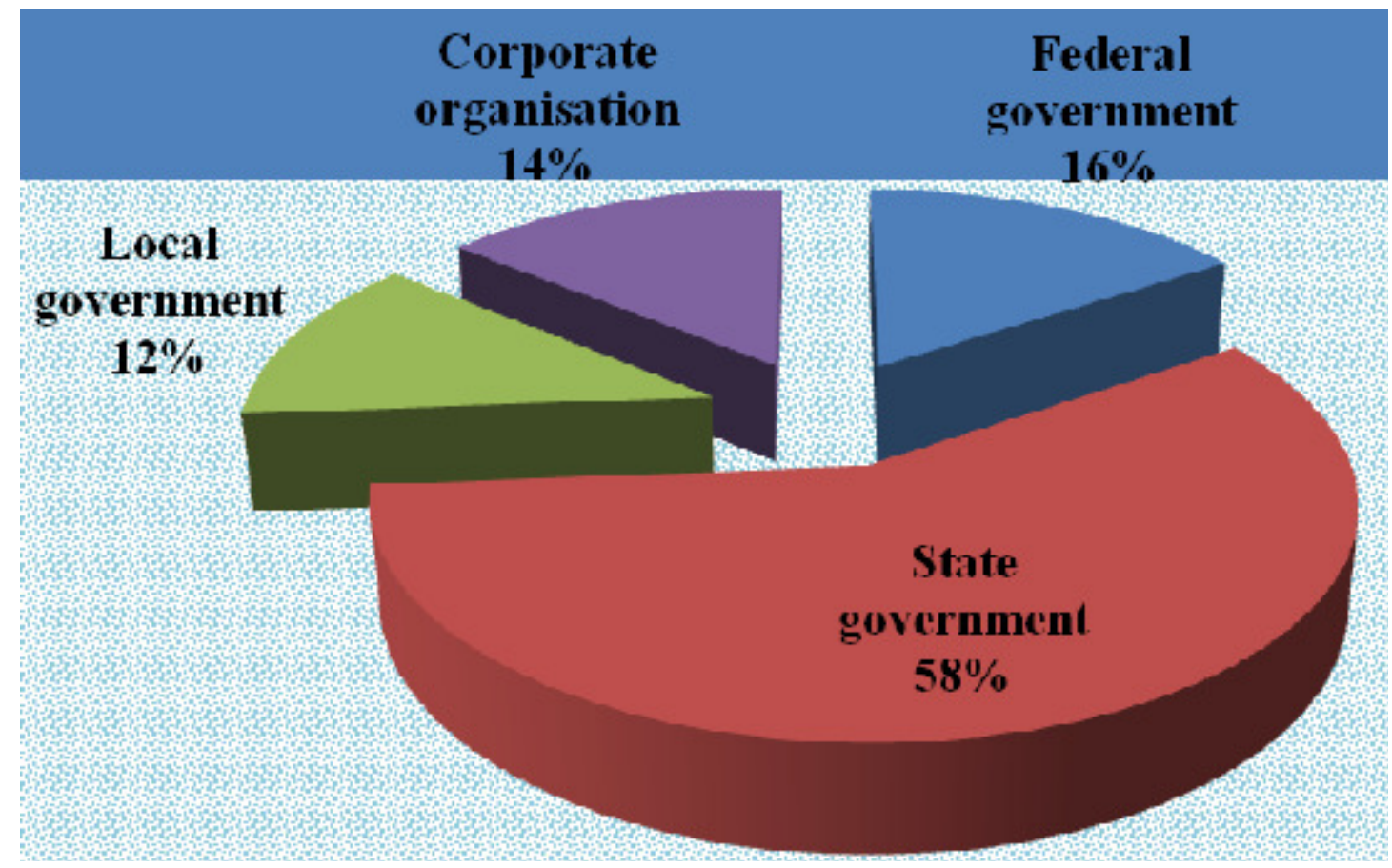

Figure 4: Institutions responsible for urban green space management

As can be seen in figure 4 above, the institutions responsible for the management of public urban green space is pictorially depicted and shows that state government is the major manager of urban green space in Ibadan metropolis with $58 \%$, federal government has $16 \%$, local government $12 \%$ while Corporate Organisations are claimed to have the remaining $12 \%$. It can therefore be deduced that the state government is a major stakeholder in the management of green space in the study area.

\section{Recommendations}

Based on the major findings of this study, the following recommendations are offered as policy issues toward a sustainable management of urban green areas in Ibadan metropolis.

1. There is need to officially commission a land use plan or at least urban renewal plan aimed at allocating spaces for greenings in the metropolis.

2. Since the highest proportion of the metropolis is concrete using hard landscaping, government should intensify efforts by making sure all available spaces such as rail lines, power lines and steep slopes as well as river courses and hilly spaces considered not fit for development are greened in order to compensate for the vast hectares of built ups in the city centre. 
3. There is also the need to reduce concrete space and Urban Heat Island (UHI) as much as possible. On this, government should evolve a legislation prohibiting the total concretization of residential, commercial and institutional areas.

4. There should be sensitization campaign on the importance of maintaining green space around human habitat and people should be mandated to keep greenings in containers both inside and outside all existing structures whether residential or commercial. Special attention should also be given to the green roofs, courtyards, green walls, streets, balconies, which integrate greening methods of reducing hard surfaces. This will go a long way in at least making up for the space concretised in the urban centres, and also serve as avenue to promote urban agriculture to achieve goal 2 of the United Nation Sustainable Development Goals 2030 (Goal 2: End hunger, achieve food security and improved nutrition and promote sustainable agriculture) (UN 2015)

5. The use of planning approval strategies to correct the past anomalies. One of the main issues in the metropolis is lack of space as virtually all space have been developed, Planning Authorities saddled with the responsibility of approval of building plans should be awake to their responsibility by ensuring that further developments in the metropolis are made to comply strictly with the $35-40 \%$ plot development standards (Obateru, 2005), so as to secure substantial space for green areas development.

6. Massive tree planting should be prioritized in the urban centres: Rather than being selective in road greenings, government should ensure that all road setbacks, median and shoulders are planted with green vegetation and tree should be planted along roads to serve as shade for pedestrians. This, aside beautification will also reduce urban temperature emanating from the macadamized road surfaces.

7. All the frontage setbacks encroached by makeshift shops and commercial activities should be demolished, tilled and made to remain green by enforcement from relevant agencies in the state. In case this is too cost for owners to carry out, government at the local and state levels should take over the job of ensuring the greening of these areas.

\section{Conclusion}

The study has examined the urban greening and city sustainability in Ibadan metropolis, Nigeria. It looks at the types of urban green space, the benefits and impediments as well as management strategies involved.

The study reveals that various types of urban green spaces exist in the study area. This ranges from residential green space, institutional green space to road greening and public squares and parks among others. It also shows that roof green space is non-existent at all in the metropolis and that the study area is predominantly concrete leaving very insignificant space for urban greening. Also, where road median and setback are left for green space development, such 
spaces are stiffly competed for with refuse dump and commercial activities. It therefore recommends land development plans, the use of planning approval instrument to enforce the maximum plot development and enlightenment campaign on green space benefits among others. All these suggestions will certainly have far reaching effects in the development and sustainability of greening in the metropolis of Ibadan in particular and Nigerian urban centres in general.

\section{References}

Adeboyejo, A.T., Lirvhuwani, M. and Shonisani, D.K. (2012). Impact of Climate Change on Children's Health in Limpopo Province, South Africa International Journal of Environmental Research and Public Health, 9: 831-854. doi:10.3390/ijerph9030831

Aldous, D.E. (2005). Education and training opportunities for turf management in Australia. Acta Horticulturae, 672: 71-7.

Baycan-Levent, T., Vreeker, R, Nijkamp, P. (2009). A multi-criteria evaluation of green spaces in European cities. European Urban and Regional Studies, 16(2): 193213.

Chiesura, A. (2004). The role of urban parks for the sustainable city. Landscape and Urban Planning, 68(1):129-138

Cohen, D.A., Inagami, S. and Finch, B. (2008). The built environment and collective efficacy. Health and Place, 14: 198-208.

Collins, A.M. (2014). Destruction of Urban Green Spaces: A Problem Beyond Urbanization in Kumasi
City (Ghana) American Journal of Environmental Protection, 3(1): 1-9

Crompton, J.L. (2001). The impacts of parks on property values: A review of the empirical evidence. Journal of Leisure Research, 33(1): 1-31.

Fam, D., Mosley, E., Lopes, A., Mathieson, L., Morison, J. and Connellan, G. (2008). Irrigation of urban green spaces: A review of the environmental, social and economic benefits. CRC for Irrigation Futures Technical Report No. 04/08.

Fanan, U., Dlama, K.I. and Oluseyi, I.O. (2011). Urban expansion and vegetal cover loss in and around Nigeria's Federal capital city. Journal of Ecology and the Natural Environment, 3(1): 1-10.

FAO (2012). Growing greener cities in Africa. First status report on urban and peri-urban horticulture in Africa. Rome: Food and Agriculture Organization of the United Nations.

Fuwape, J.P. and Onyekwelu, J.C. (2011). Urban Forest Development in West Africa: Benefits and Challenges. Journal of Biodiversity and Ecological Sciences, 1(1): 7894.

Hall, P. and Tewdwr-Jones, M. (2010). Urban and Regional Planning. Routledge.

Jibril, I.U. (2010). The Return of the Greens in Abuja, Nigeria's New Capital City. FIG Congress 2010.Sustainable Planning and Urban Renewal Facing the Challenges - Building the Capacity. Sydney, Australia.

Mckinney, M.L. (2002). Urbanization, biodiversity, and conservation. BioScience 52: 883-890. 
NPC (2006). National Population Census of Nigeria. Federal. Republic. Nigeria.

Obateru, O.I. (2005). Space standards for urban development. Ibadan: Penthouse Publications (Nig.)

Opkala, D. (2009). Regional overview of the status of urban planning and planning practice in Anglophone (Sub-Saharan)

African countries.[Online]. Available on http://www.unhabitat.org/download s/docs/GRHS.2009.Regional.Anglo phone.Africa.pdf

Solecki, W., Patrick, L., Grady, K., Cox, J. and Ervin, K. (2008). Urban Forests in Our Midst: Environmental Benefits of Open Spaces in City Backyards. CUNY Institute for Sustainable Cities, Hunter College, New York, www.landmarkwest.org,

United Nations (2015). "Transforming our world: The 2030 Agenda for
Sustainable Development". United Nations - Sustainable Development knowledge platform. Retrieved23rd August 2015

URGE, (2004). (Development of urban green spaces to improve the quality of life in cities and urban regions). Making greener cities: A practical guide. (Section C "Good practice"). Leipzig: UFZ Centre for Environmental research LeipzigHalle. Retrieved October 16, 2005, from URGE Web site: http://www.urge-project.ufz.de/CD/ booklet.htm.

Wahab, B. (2011). Ibadan: A rapidly growing city in need of a Master Plan. Paper read at the Architects' Congress/Annual General Meeting organized by the Nigerian Institute of Architects, Oyo State Chapter, held at Penrose Event Centre, Obafemi Awolowo Avenue, Old Bodija Estate, Ibadan, July 7. 